\title{
Implications of bovine viral diseases for udder health
}

\author{
As implicações das doenças virais para a saúde da glândula mamária bovina
}

\author{
Aline de Jesus da SILVA'; Fernando Nogueira de SOUZA'; Maiara Garcia BLAGITZ1'; Camila Freitas BATISTA'; Jéssyca \\ Beraldi BELLINAZZI'; Deisiane Soares Murta NOBRE'; Kamila Reis SANTOS'; Alice Maria Melville Paiva DELLA \\ LIBERA ${ }^{1}$
}

${ }^{1}$ Universidade de São Paulo, Faculdade de Medicina Veterinária e Zootecnia, Departamento de Clínica Médica, São Paulo - SP, Brazil

\begin{abstract}
Several factors can affect bovine mammary gland health and although bacterial mastitis is the most studied and reported cause, viral infections may also have negative effects on bovine udder health. Viral infections can indirectly damage the papillary duct of the teat, and induce or exacerbate signs of bovine mastitis due to viral-induced immunosuppressive effects that may lead to a greater susceptibility to bacterial mastitis and even intensify the severity of established bacterial infections. Some viruses (Bovine alphaherpesvirus 2, cowpox, pseudocowpox, foot-and-mouth disease, vesicular stomatitis and papillomavirus) affect the integrity of the udder skin, leading to teat lesions, favoring the entry of mastitis-causing pathogens. It is therefore possible that the association between mastitis and viruses is underestimated and may, for example, be associated with negative bacterial culture results. Few milk samples are tested for the presence of viruses, mainly because of the more laborious and expensive procedures required. Furthermore, samples for virus testing would require specific procedures in terms of collection, handling and storage. Thus, there is a knowledge gap in regard to the actual impact of viruses on bovine udder health. Despite the fact that serum anti-virus antibodies can be detected, there is not enough evidence to confirm or exclude the effect of viruses on udder health. However, any expectation of milk production from healthy animals should consider the possible impact of viral infections in mastitis development and not underestimate the importance of actions to diagnose and control the disease. Therefore, the purpose of this review is to describe the association of diagnosis and control of viral diseases and their effect on bovine udder health.
\end{abstract}

Keywords: Cattle. Milk. Mastitis. Virus.

\section{Resumo}

Diversos fatores podem afetar a saúde da glândula mamária bovina e embora a mastite bacteriana seja a causa mais estudada e relatada, as infecções virais também podem ter efeitos negativos sobre a saúde da glândula mamária bovina. De forma indireta as infecções virais podem danificar o ducto papilar do teto ou ainda, induzir ou agravar a mastite bovina, devido aos seus efeitos imunossupressores que podem levar a uma maior susceptibilidade para casos de mastite bacteriana e até mesmo intensificar a severidade das infecções bacterianas já estabelecidas. Alguns vírus (Alphaherpesvirus bovino 2, cowpox, pseudocowpox, febre aftosa, estomatite vesicular e papilomavírus) afetam a integridade da pele do úbere, levando a lesões no teto, favorecendo a entrada de patógenos causadores de mastite. Portanto é possível que a associação entre mastites e viroses seja subestimada e podem, por exemplo, estar associada às amostras de diagnóstico de mastite bacteriana com resultados de cultura bacteriana negativa. Além disso, as amostras de leite de vacas com mastite não são coletadas, tratadas e armazenadas adequadamente para pesquisa de vírus que requer cuidados específicos, além de um diagnóstico mais trabalhoso e caro. Desse modo, há lacunas a serem preenchidas quanto ao real impacto das viroses sobre a saúde da glândula mamária bovina. Apesar da possibilidade de detecção de anticorpos séricos contra os vírus, não existem evidências suficientes para incluir ou excluir os efeitos das viroses a saúde da glândula mamária bovina. Porém, a expectativa de produção de leite por meio de animais saudáveis deve considerar os possíveis impactos das infecções virais no desenvolvimento de mastites, não se pode, portanto, subestimar a importância de ações para o diagnóstico e controle das mesmas. Sendo assim, o propósito desta revisão é descrever as relações entre o diagnóstico de controle das doenças virais e seus potenciais impactos sobre a saúde da glândula mamária bovina.

Palavras-chave: Bovinos. Leite. Mastite. Vírus. 
Correspondence to:

Aline de Jesus da Silva

Universidade de São Paulo, Faculdade de Medicina Veterinária

e Zootecnia, Departamento de Clínica Médica

Av. Prof. Dr. Orlando Marques de Paiva, 87

CEP 05508-270, São Paulo, SP, Brazil

e-mail: aline_med.vet@hotmail.com

Received: 27/10/2017

Approved: 03/09/2018

\section{Introduction}

Health of the bovine mammary gland undoubtedly affects milk quality and is predominantly caused by bacterial infections. However, it is well-known that bovine mammary gland health is influenced by other risk factors such as nutrition deficiencies (SILVA et al., 2014), stress (PORCIONATO et al., 2009), and foot conditions (RODRIGUES et al., 2017), among others.

These factors, predisposing cows to mastitis, have direct consequences on the reduction of milk quality and production. In this perspective, would circulating viruses really adversely affect mammary gland health? Would the viruses impact mammary gland health directly or indirectly?

Although effective mastitis control measures successfully implemented in several countries based on the 10 mastitis control points established by the National Mastitis Council (NMC, 2016) reduced the occurrence of intramammary infections by major infectious pathogens such as Streptococcus agalactiae and Staphylococcus aureus, mastitis is still a major challenge for the milk production chain. For example, intramammary infections by non-aureus Staphylococci (NAS) and environmental opportunistic pathogens still affect a significant proportion of dairy cows in countries that have effectively implemented programs for the control of bovine mastitis (CARSON et al., 2017).

The bovine mammary gland can be considered as an immunological anomaly, due to the lack of efficiency of its protective mechanisms (TIZARD, 2014). In fact, resilience leads dairy cows, which are in close interaction with humans and increasing environmental challenges, to adapt their mammary system to different threats.
As a result of these adaptations, variations in susceptibility to intramammary infections are observed, which have undesirable consequences for milk quality when compared to that required by costumers and the dairy industry (BRASIL, 2016).

Wellenberg et al. (2002) reported that several factors can affect mammary gland health, and, although bacterial mastitis is the most studied and reported cause, viral infections may also negatively directly or indirectly affect the mammary gland. Some bovine viral diseases are more widespread and occur throughout Brazil (LIMA, 2013). Considering the possibility that these diseases can also affect mammary gland health, their economic impact is usually underestimated (WELLENBERG et al., 2002).

To measure the consequences of a bovine virus infection, it is important to determine its economic effects, lethality and the affected target organ. Considering the impact on lethality or international trade, we would regard rabies and foot-and-mouth diseases as the major bovine viruses. Because infected animals will not survive or will be legally culled, udder health is not the primary concern for these diseases (BRASIL, 2005, 2007). As for the target organ or system involved, the viruses are more commonly classified as reproductive, respiratory, gastrointestinal, integumentary and neurological, and not infrequently, they affect more than one system, with different behaviors according to viral subtypes. To some degree they may also affect mammary gland health, causing mastitis or predisposing animals to mastitis, subsequently impairing milk production and quality.

Viral infections may play an indirect role in the pathogenesis of bovine mastitis to damage the papillary duct of the teat. Or, they may induce or aggravate bovine mastitis due to immunesuppressive effects that may lead to a greater susceptibility to cases of bacterial mastitis and even amplify the severity of established bacterial infections (WELLENBERG et al., 2002). Some viruses (Bovine alphaherpesvirus 2, cowpox, pseudocowpox, footand-mouth disease, vesicular stomatitis and 
papillomavirus) affect the integrity of the udder skin, leading to teat lesions, favoring the entry of mastitiscausing pathogens (CHEN et al., 2017a, 2017b).

Immunosuppression and viral disease are correlated conditions, since the virus is an obligate intracellular parasite that compromises host immune response to establish or allow an infection to persist. It is possible that the association between mastitis and viruses is underestimated and may, for example, be associated with routine diagnosis only for bacterial mastitis and the large number of bacteriologically negative samples. Besides, milk samples from mastitis-infected cows are not collected, treated and stored properly for virus research that requires specific care, in addition to a more laborious and expensive diagnosis. Therefore, the purpose of this review is to describe the association of diagnosis and control of viral diseases and their effect on bovine udder health.

\section{Bovine alphaherpesvirus 1}

Bovine alphaherpesvirus 1 (BHV-1) belongs to the family Herpesviridae, subfamily Alphaher-pesvirinae, Varicellovirus genus and is widely disseminated, causing great economic losses, since it is a virus of high prevalence in bovine herds (NUOTIO et al., 2007; ICTV, 2018). According to Muylkens et al. (2007), BHV-1 can be differentiated into subtypes $1.1,1.2 \mathrm{a}$, and $1.2 \mathrm{~b}$, because the BHV-1.3, has been reclassified as BHV-5 (NANDI et al., 2009).

It is the causative agent of infectious bovine rhinotracheitis (IBR), infectious pustular vulvovaginitis (IPV) and infectious pustular balanoposthitis. These viruses have as biological properties the induction of latent infections, that is, once infected, the host remains a virus reservoir for life (GRAHAN, 2013).

According to data reviewed by Wellenberg et al. (2002), although it is associated with different clinical forms of infections of the respiratory, genital and reproductive systems, BHV-1 was associated with bovine mastitis when it was isolated from an infected cow in the United States. However, evidence that the virus caused mastitis was circumstantial, as the milk sample was collected three days after vaccination with a live vaccine for IBR.

In another report, the virus was isolated from vesicular lesions in the udder and on the teat of a cow, so it was associated with skin lesions of the bovine udder. However, there was difficulty in determining whether the lesions were caused by BHV-1 infection (GUY et al., 1984).

In the same year, Siegler et al. (1984) reported a high incidence of mastitis cases in several cow herds infected with BHV-1 and BVDV. In addition, authors suggested a possible role of BHV-1 in the etiology of bovine mastitis, associated or not with BVDV, since it was observed that the immunization of these affected cows with IBR / IPV vaccine, combined or not with the BVDV vaccine, resulted in effective control of mastitis problems.

In another study conducted by Straub and Kielwein (1966), where intramammary inoculation with BHV1-IPV triggered clinical mastitis with an evident increase in body temperature, reduced appetite, painful and swollen udder, and a strong reduction in milk yield, it was still possible to isolate the virus in the milk of quarters inoculated until the $11^{\text {th }}$ day post infection.

In contrast to previous studies, Wellenberg et al. (2000) failed to isolate BHV-1 from the milk of any of the 58 cases of natural clinical mastitis in 10 herds examined; therefore, these authors considered that BHV-1 is probably not an important primary pathogen of the udder.

On the other hand, Rola et al. (2015) examined the effect of BHV-1 infection on milk quality in cattle and found a significant association between BHV-1 infection and tank milk somatic cell count (SCC), suggesting that the pathogen induces not only the decrease in milk production in a herd, but also milk quality and reproductive losses.

\section{Bovine alphaherpesvirus 2}

Bovine alphaherpesvirus 2 (BHV-2) belongs to the family Herpesviridae, subfamily Alphaher-pesvirinae, genus Simplexvirus (ROIZMAN et al., 1992; ICTV, 2018). It is the etiological agent of herpetic 
mammillitis in bovines, characterized by vesicular and erosive lesions in the teat or udder of affected animals (TORRES et al., 2009).

Due to the manifestation of this infection, lesions impair the milking routine, predispose the animals to mastitis, reduce milk production, and lead to premature culling of affected cows (GIBBS; RWEYEMAMU, 1977). These lesions are restricted more to the teat and udder of the animal, since the ideal temperature for replication of BHV-2 is lower than the normal body temperature, a condition offered by the mammary gland (LETCHWORTH; CARMICHAEL, 1984).

According to Gibbs et al. (1973), once BHV-2 is introduced into a herd, carriers of the latent infection perpetuate this condition and occasionally reactivate the infection and transmit it to susceptible animals.

A study by Dardiri and Stone (1972) revealed a BHV-2 prevalence of $20 \%$ in herds in North America and Great Britain (RWEYEMAMU et al., 1969). In Switzerland, a seroprevalence of $7 \%$ was detected (ENGELS et al., 1979). In Brazil, bovine herpetic mammillitis was first described in the 1970s and 1980s (CASTRO et al., 1988). After the first reports, Torres et al. (2009) observed, in a majority of the regions of the state of Rio Grande do Sul, a tendency of dairy herds to present higher seroprevalence than mixed and beef cattle herds.

Although the studies related to this disease are still scarce, they demonstrate the health significance of herpetic mammillitis that is even recognized in several countries, especially in dairy herds. It is important to emphasize that factors such as intensive management, congregation of animals and management practices during milking of these animals may favor the spread of the agent by the herd (SCOTT et al., 1978).

\section{Bovine gammaherpesvirus 4}

Bovine gammaherpesvirus 4 (BHV-4) belongs to the subfamily Gammaherpesvirinae and genus Rhadinovirus (KRÜGER, 2012; ICTV, 2018). It was the first herpes virus isolated in Europe from animals with respiratory and ocular diseases (BARTHA et al.,
1966) and later in the United States (MOHANTY et al., 1971).

Among all viruses in this family, BHV-4 is the most intriguing because it is isolated in apparently healthy cattle, as well as in a wide range of clinical conditions, such as abortion, skin lesions, metritis, mastitis, ulcerative mammillitis, bladder and rumen tumors, cases of malignant catarrhal fever and ocular, respiratory, genital, enteric and neurological infections (ASANO et al., 2003; DEWALS et al., 2006), mammary pustular dermatitis (REED et al., 1977), and mammary ulcerative dermatitis (CAVIRANI et al., 1990).

In a study carried out by Zadoks et al. (2001), intramammary and intranasal inoculation did not simultaneously result in clinical mastitis; only two of four inoculated cows showed subclinical mastitis. There was also an increase in SCC in 50\% of inoculated quarters and the virus was only recovered from inoculated quarters. S. uberis appeared to trigger BHV-4 replication in experimentally infected cows two weeks earlier with the virus, which was isolated from the milk in half of the samples after inoculation with $S$. uberis. Authors also reported a positive association between BHV-4 antibodies and mastitis caused by $S$. aureus, suggesting that previous infection with BHV-4 predisposes mastitis to $S$. aureus.

Donofrio et al. (2000) reported that although no clinical evidence of mastitis was recorded, BHV-4 was isolated from the milk cell fraction of cows with antibodies against it. Therefore, it is more likely that if BHV-4 causes mastitis, it would be subclinical, or it would participate in the transmission route as a predisposing factor. The possibility of causing immunosuppression, or perhaps only its involvement with the immune system, is due to the fact that it infects macrophages and cause damage to vascular tissue (LIN et al., 2000). This fact leads to some question whether milk could then be a source of infection, since bovine endothelial cell cultures are highly susceptible to BHV-4.

Donofrio et al. (2000) did not define the type of cell that carries the virus in milk. However, the 
demonstration that BHV-4 can establish a persistent infection in lymphoid tissues and prolonged viremia associated with the peripheral blood mononuclear cell fraction could explain the recovery of the virus in milk because of transport through the lymphatic and circulatory systems.

The humoral immune response following BHV-4 infection in cattle is characterized by the production of neutralizing antibodies of low avidity. The lack of neutralizing antibodies in the milk and colostrum of infected cows may favor the trans-mission of BHV-4 to calves. Thus, contact with infectious milk plays a role in virus transmission, or the stage at which BHV4 shedding in milk occurs is unknown (KRÜGER, 2012).

\section{Parainfluenza virus 3}

The Parainfluenza virus type 3 (PI-3) belongs to the family Paramyxoviridae, genus Paramyxovirus and is responsible for respiratory infections in cattle and sheep (MURPHY et al., 1999; GONÇALVES et al., 2003; ICTV, 2018).

Kawakami et al. (1966) reported an epidemic of acute respiratory disease, where several strains of the PI-3 virus were isolated. The peculiarity was that in many cases the virus was recovered not only from nasal discharges, but also from milk. Therefore, this finding was important in understanding the pathogenesis and epidemiology of infection in cattle, suggesting a possible role of this virus in mastitis.

The same authors also reported the signs and clinical findings caused by PI-3 in the mammary gland, including edema, soreness, milk color change, increase in $\mathrm{pH}$, increase in number of glandular epithelial cells, neutrophils, lymphocytes and monocytes, virus shedding in milk, and interstitial inflammation (with large lymphoid cells). Kawakami et al. (1966) indicated that the mammary gland is highly susceptible to PI-3 and that natural infection of the udder occurs, which in some cases may result in clinical mastitis.

\section{Bovine Viral Diarrhea Virus - BVDV}

Bovine Viral Diarrhea Virus (BVDV) belongs to the Flaviviridae family, genus Pestivirus, (HORZINEK, 1991; ICTV, 2018). This is one of the major cattle pathogens and causes significant economic losses for cattle breeding worldwide (BAKER, 1995).

Persistently infected (PI) animals show chronic respiratory failure (ROTH et al., 1986; BROWNLIE, 1989), and delayed onset of Bovine Respiratory Syncytial Virus (BRSV), specific IgG response and reduced antibody titers were observed in cattle simultaneously with BVDV (ELVANDER, 1996). These data indicate that BVDV may play a direct or indirect role in the susceptibility of the animal to secondary infections leading to a more severe disease course (POTGIETER et al., 1984).

Studies on the immunosuppressive role of BVDV in relation to bovine mastitis are scarce. Siegler et al. (1984) reported an increased number of mastitis cases in BVDV and BHV-1 seropositive herds, but the role of BVDV in these cases of mastitis is questionable, as it is unclear. In addition, a positive association between BVDV and bovine mastitis has been reported, based on BVDV antibody titers in bulk milk from 237 herds. The number of mastitis cases increased in herds with an increased antibody titer to BVDV in milk (NISKANEN et al., 1995).

In a retrospective longitudinal study, which was conducted to examine whether exposure of dairy herds to BVDV affected udder health, a 7\% increase in the incidence of clinical mastitis was observed in BVDV-exposed herds compared to non-exposed herds to BVDV (WAAGE, 2000). A reduction in milk yield was observed in cows that had seroconverted to BVDV antibodies, although no information on mastitis was reported (MOERMAN et al., 1994).

As far as it can be compiled, more studies are needed to clarify the role of BVDV in bovine mastitis. To date, no intramammary inoculation of cows with BVDV has been reported and, moreover, there are no 
reports on the isolation of BVDV from cows with mastitis. However, BVDV genomic sequences were detected by PCR in milk samples (RADWAN et al., 1995; DREW et al., 1999), but this was probably caused by the presence of persistently infected cows in the herd; consequently, it doesn't necessarily mean that the virus is involved directly or indirectly in cases of bovine mastitis.

\section{Vaccinia virus}

Vaccinia virus (VACV) has an uncertain origin. According to Moss (2007), VACV appears to have evolved from the extinct Horsepox virus or bovine Papillomavirus (BPV), which is antigenically very similar to VACV.

Vaccinia virus infections are characterized by exanthematic lesions in the udder and teat of lactating cows, also affecting the hands and forearms of milkers (LOBATO et al., 2005; REHFELD et al., 2017).

Transmission of the VACV between animals occurs mainly through the hands of milkers and the milking equipment, since penetration of the virus occurs through wounds in pre-existing lesions in the teat and udder of cows (TRINDADE et al., 2003).

Rehfeld et al. (2013) detected the virus directly in $100 \%$ of wound crusts in affected animals from rural properties in the state of Minas Gerais, as well as viral DNA in $22 \%$ of milk samples, $8.5 \%$ in blood samples and $10.2 \%$ in feces of symptomatic dairy cows. In the same study, virus DNA was also detected in $16.7 \%$ of calf blood samples and $30 \%$ in asymptomatic dry cows. Interestingly, viremia was detected in other categories of dairy cattle, such as cows and healthy bulls. In addition to viremia, virus circulation in peripheral farms and other dairy products can be detected by serology. Neutralizing antibodies were detected in 53.8\% (7/13) of cattle asymptomatic from farms affected by VACV and in $53.8 \%$ (14/26) of farms.
Neutralizing antibodies and VACV DNA were also detected in serum samples from asymptomatic dairy cows in Argentina and Uruguay (FRANCO-LUIZ et al., 2014, 2016), although it is curious that no disease outbreaks have ever been reported in the herds where the cows were located.

In recent years, several outbreaks of bovine pox in different regions of Brazil occurred that also affected humans, showing that this disease emerged as a zoonosis (LOBATO et al., 2005). The data presented suggest new hypotheses regarding the epidemiology of VACV and shows a potential source of virus dissemination, which contribute to the persistence and dissemination of the virus in the environment.

\section{Pseudocowpox virus}

The Pseudocowpox virus belongs to the genus Parapoxvirus, its distribution is worldwide and it is the etiological agent of pseudocowpox (PCPV) (ICTV, 2018). Pseudocowpox virus infection is an occupational disease in milkers and veterinarians, affecting other people who handle fresh milk, and considered accidental in humans (BARRAVIEIRA, 2005).

This disease mainly affects dairy cows in unsatisfactory hygienic-sanitary conditions. It can be transmitted by direct and indirect contact with the lesions. Thus, it can be classified as indirect pathways to widespread transmission of the virus through feeding calves directly on teat of affected cows, flies as mechanical vectors, and contaminated milk equipment (LEMOS; RIET-CORREA, 2001; CANAL; FLORES, 2007).

According to Lemos and Riet-Correa (2001), there is no seasonal variation in the incidence of bovine pseudocowpox, and virus penetration is due to wounds in pre-existing lesions in the teat and udders of cows.

In cattle, the infection is endemic, causing lesions in the udder, thorax, limbs and oral cavity, leading to the formation of pustules and crusts (MERCER et al., 
2007). After human contact with infected animals, and an incubation period between five and 15 days, lesions manifest as flattened erythematous papules, and evolve into erythematous violet nodules. Skin then becomes opaque, grayish with small crusts, and with a central depression, and nodules can occur in small amounts on the hands, particularly the fingers and occasionally on the face (BARRAVIEIRA, 2005).

Infection caused by the PCPV virus does not confer adequate adaptive immunity and although reinfection may occur in the same herd, which is more common, chronic infections may occur less frequently and prior infection with the Orthopoxvirus that affects cattle does not appear to protect animals from PCPV (KAHRS, 2001; CANAL; FLORES, 2007).

Considering how easy the agent disperses, prevention consists of using gloves and disinfectants before and after milking or handling of these animals (BARRAVIEIRA, 2005).

\section{Bovine leukemia virus}

Bovine enzootic leukosis is an infectiouscontagious disease caused by Bovine leukemia virus (BLV) that belongs to the family Retroviridae, subfamily Orthoretrovirinae and genus Deltaretrovirus (SOUZA et al., 2011; ICTV, 2018). Although it has been successfully eradicated in some regions of Europe, BLV is one of the most widespread pathogens of livestock in many countries, especially in dairy herds (SOUZA et al., 2011).

BLV infection in cattle may remain clinically silent or may appear as persistent lymphocytosis (LP) and, more rarely, develop B-cell lymphoma. LP is characterized as a chronic elevation in the number of circulating B lymphocytes, and is found in approximately 20 to $30 \%$ of cattle infected with BLV (GILLET et al., 2007).

According to Leuzzi Junior et al. (2001), bovine enzootic leukosis can also occur by vertical transmission through the uterine or even oral route, through the ingestion of colostrum and milk containing lymphocytes contaminated with VLB.
Bovine enzootic leukosis also affects milk production by the direct action of the virus in the mammary gland, since BLV has already been detected in lymphocytes (YOSHIKAWA et al., 1997), epithelial cells of the mammary gland (BUEHRING et al., 1994), in addition to being able to initiate the transformation of these mammary cells and lead to a reduction in casein production in vitro (MOTTON; BUEHRING, 2003).

These effects of BLV infection in general and directly on the mammary gland may also be related to the higher incidence of mastitis and higher SCC observed by some authors in infected animals (WELLENBERG et al., 2002). Furthermore, Sandev et al. (2004) found that the incidence of subclinical mastitis was higher in animals infected with BLV with LP, probably associated with its immunesuppressive effect.

A study by Rajão et al. (2014) observed lower milk production in pure high-production animals infected with BLV when compared to uninfected animals, indicating that the infected animals may not be reaching their productive potential, causing losses to the producer, resulting in early animal culling.

Thus, the global impact of some chronic diseases with low lethality rates, such as BLV infection, may be underestimated because of the association with comorbidities (DELLA LIBERA et al., 2015). It is known that different viruses can affect the function of the innate and adaptive immune system (SOUZA et al., 2012; DELLA LIBERA et al., 2015; BLAGITZ et al., 2017). In this context, cases of mastitis and low milk production related to BLV infection, especially in animals with LP, are associated with the fact that milk neutrophils have a negative impact on the eradication of pathogens, having phagocytic capacity and intracellular production of reactive species of oxygen (microbicidal capacity) impaired, which may be directly implicated in mastitis control programs (DELLA LIBERA et al., 2015).

Erskine et al. (2011) tested the effect of BLV on the serological response to an Escherichia coli J5 bacterin that is administered in dairy cattle. In this study, antibody titers (IgG1 and IgG2) were 
significantly lower in dairy cows infected by BLV when compared to uninfected cows, which may show implications of the virus for mammary gland health.

The authors explain that BLV induces changes in the complex balance of cytokine expression, cell proliferation and apoptosis in B lymphocytes.

\section{Milk as a Source of Viral Infection}

The control of viruses could be important based not only by their direct damage, but also because of immunosuppression that predisposes animals to comorbidities, such as mastitis, which is the costliest disease in dairy cattle (DELLA LIBERA et al., 2015; LYONS et al., 2015). One of the major aspects of virus control that should be considered is to immunize dairy cattle under risk and avoid contact of calves, especially calves from infected cows, with secretions of these animals, as well as the con-sumption of raw milk and/or colostrum (CHEN et al., 2017b).

It has long been known that BLV is eliminated by the mammary gland (ROMERO et al., 1982, 1983), and that raw milk and colostrum from BLV-infected animals is an important source of infection for calves. Thus, a critical preventive method should be the use of cell-deprived, frozen or heat inactivated secretions (milk/colostrum) to render them non-infectious feed to calves (KANNO et al., 2014; GUTIÉRREZ et al., 2015; JAWORSKI et al., 2016). Another alternative would be to use milk/colostrum from a negative cow to prevent the transmission of BLV. It is also recommended that these animals be tested at about six months of age to be sure that viral transmission

\section{Reference}

ASANO, A.; INOSHIMA, Y.; MURAKAMI, K.; IKETANI, Y.; YAMAMOTO, Y.; SENTSUI, H. Latency and persistence of bovine herpesvirus type 4, strain b1141 , in bovine nervous tissues. Journal of Veterinary Medical Science, v. 65, n. 1, p. 87-93, 2003.

BAKER, J. C. The clinical manifestations of bovine viral diarrhea infection. Veterinary Clinics of North America: Food Animal Practice, v. 11, n. 3, p. 425-445, 1995. did not occur (BRAGA et al., 1998). However, another study by Braga et al. (1997) using this same methodology, reported that it is possible to have negative calves from positive cows.

According to Chen et al. (2017a), several viral agents have been isolated from mastitis cases, such as BHV-1, BHV-4, foot-and-mouth disease and PI-3, suggesting that these pathogens can be transmitted via milk. This is due to the fact that possibly some viruses (BHV-2, cowpox, pseudocowpox, foot-andmouth disease, vesicular stomatitis and papillomavirus) affect the integrity of the udder causing damage to the teat skin and favoring the entrance of mastitis pathogens (CHEN et al., 2017a, 2017b). To corroborate this, Goraya et al. (2015) found that buffaloes infected with buffalopox were predisposed to mastitis due to lesions in the udder and teat, leading to compromised milk production.

\section{Conclusion}

A knowledge gap exists regarding the real impact of viruses on bovine udder health. Even with detection of anti-virus serum antibodies, there is not enough evidence to include or exclude the effects of viruses on bovine udder health. However, any expectation of milk production through healthy animals should consider the possible impact of viral infections in mastitis development, and not underestimate the importance of actions to diagnose and control the disease.

BARRAVIEIRA, S. R. C. S. Diseases caused by Poxvirus - Orf and Milker's nodules - a review. Journal of Venomous Animals and Toxins including Tropical Diseases, v. 11, n. 2, p. 102-108, 2005. doi: 10.1590/S1678-91992005000200002.

BARTHA, A.; JUHASZ, M.; LIEBERMANN, H. Isolation of a bovine herpesvirus from calves with respiratory disease and keratoconjuntivitis. Acta Veterinaria Academiae Scientiarum Hungaricae, v. 16, n. 3, p. 357-358, 1966. 
BLAGITZ, M. G.; SOUZA, F. N.; BATISTA, C. F.; AZEVEDO, L. F.; SANCHEZ, E. M.; DINIZ, S. A.; SILVA, M. X.; HADDAD, J. P.; DELLA LIBERA, A. M. M. P. Immunological implications of bovine leukemia virus infection. Research in Veterinary Science, v. 114, p. 109-116, 2017. doi: 10.1016/j.rvsc.2017.03.012.

BRAGA, F. M.; VAN DER LAAN, C. W.; HALFEN, D. C.; VIDOR, T. Avaliação de métodos de controle da infecção pelo vírus da leucose enzoótica bovina. Ciência Rural, v. 27, n. 4, p. 635-640, 1997. doi: 10.1590/S0103-84781997000400019.

BRAGA, F. M.; VAN DER LAAN, C. W.; SCHUCH, L. F.; HALFEN, D. C. Infecção pelo virus da leucose enzoótica bovina (BLV). Ciência Rural, v. 28, n. 1, p. 163-172, 1998. doi: 10.1590/S0103-84781998000100029.

BRASIL. Ministério da Agricultura, Pecuária e Abastecimento. Instrução Normativa $n^{\circ} 44$, de 2 de outubro de 2007. Aprova as diretrizes gerais para a Erradicação e a Prevenção da Febre Aftosa. Diário Oficial da União, no 191, de 3 de outubro de 2007, seção 1, pág 2 a 10.

BRASIL. Ministério da Agricultura, Pecuária e Abastecimento. Instrução Normativa $n^{\circ} 7$ de 03 de Maio de 2016. Altera a Instrução Normativa ${ }^{\circ} 62$, de 29 de dezembro de 2011, que aprova o Regulamento Técnico de Produção, Identidade e Qualidade do Leite tipo A, o Regulamento Técnico de Identidade e Qualidade de Leite Cru Refrigerado, o Regulamento Técnico da Coleta de Leite Cru Refrigerado e seu Transporte a Granel. Diário Oficial da União, nº 84 , de 04 de maio de 2016, Seção 1, pág. 11.

BRASIL. Ministério da Agricultura, Pecuária e Abastecimento. Portaria SDA $\mathrm{N}^{\circ} 168$, de 27 de setembro de 2005. Aprovar o MANUAL TÉCNICO PARA O CONTROLE DA RAIVA DOS HERBÍVOROS. Diário Oficial da União, nº 188, de 29 de setembro de 2005, seção 1, p. 9.

BROWNLIE, J. Bovine virus diarrhoea virus: a crisis for the immune system. In: INTERNATIONAL SYMPOSIUM OF THE WORLD ASSOCIATION OF VETERINARY MICROBIOLOGISTS, IMMUNOLOGISTS AND SPECIALIST IN INFECTIOUS DISEASES, 11., 1989, Italy. Proceedings... Mantova: Associazione Mantovana Allevatori, 1989. p. 247-252.

BUEHRING, G. C.; KRAMME, P. M.; SCHULTZ, R. D. Evidence for bovine leukemia virus in mammary epithelial cells of infected cows. Laboratory Investigation, v. 71, n. 3, p. 359-365, 1994.
CANAL, C. W.; FLORES, E. F. Poxviridae. In: CANAL, C. W.; FLORES, E. F. Virologia veterinária. Santa Maria: Ed. UFSM, 2007.

CARSON, D. A.; BARKEMA, H. W.; NAUSHAD, S.; DE BUCK, J. Bacteriocins of Non-aureus Staphylococci Isolated from Bovine Milk. Applied and Environmental Microbiology, v. 83, n. 17, e01015-17, p. 1-21, 2017. doi: 10.1128/AEM.01015-17.

CASTRO, R. S.; LEITE, R. C.; LOBATO, Z. I. P. Relato de um surto de "pseudo lumpy skin disease" em novilhas importadas, em Minas Gerais, Brasil. Arquivo Brasileiro de Medicina Veterinária e Zootecnia, v. 40, n. 4, p. 305-311, 1988.

CAVIRANI, S.; ALLEGRI, G.; FLAMMINI, C. F. Isolation of bovine herpesvirus-4 (BHV-4) from cows affected by chronic ulcerative mammary dermatitis. Estratto da Selezione Veterinaria, v. 31, p. 1251-1260, 1990.

CHEN, N.; WANG, F.; YU, N.; GAO, Y.; HUANG, J.; DANG, R.; HUANG, Y.; LAN, X.; LEI, C.; CHEN, H. Polymorphisms in MX2 gene are related with scs in chinese dairy cows. Animal Biotechnology, v. 29, n. 2, p. 81-89, 2017a. doi: 10.1080/10495398.2017.1307217.

CHEN, N.; WANG, F.; YU, N.; GAO, Y.; HUANG, J.; HUANG, Y.; LAN, X.; LEI, C.; CHEN, H.; DANG, R. Genetic variations of the bovine $M X 1$ and their association with masttis. Czech Journal of Animal Science, v. 62, n. 4, p. 157-167, 2017b. doi: 10.17221/97/2015-CJAS.

DARDIRI, A. H.; STONE, S. S. Serologic evidence of dermophatic bovine herpesvirus infection of cattle in the United States of America. Proceedings Annual Meeting of the United States Animal Health Association, v. 76, p. 156-171, 1972.

DELLA LIBERA, A. M. M. P.; SOUZA, F. N.; BATISTA, C. F.; SANTOS, B. P.; AZEVEDO, L. F. F.; RAMOS SANCHEZ, E. M.; DINIZ, S. A.; SILVA, M. X.; HADDAD, J. P.; BLAGITZ, M. G. Effects of bovine leukemia virus infection on milk neutrophil function and the milk lymphocyte profile. Veterinary Research, v. 46, n. 2, p. 1-8, 2015. doi: 10.1186/s13567-014-0125-4.

DEWALS, B.; THIRION, M.; MARKINE-GORIAYNOFF, N.; GILLET, L.; FAYS, K.; MINNER, F.; DAIX, P. M. S.; VANDERPLASSCHEN, A. Evolution of Bovine herpesvirus 4: recombination and transmission between African buffalo and cattle. Journal of General Virology, v. 87, p. 1509-1519, 2006. doi: 10.1099/vir.0.81757-0. 
DONOFRIO, G.; FLAMMINI, C. F.; SCATOZZA, F.; CAVIRANI, S. Detection of bovine herpesvirus 4 (BoHV-4) DNA in the cell fraction of milk of dairy cattle with history of BoHV-4 infection. Journal Clinical Microbiology, v. 38, n. 12, p. 4668-4671, 2000.

DREW, T. W.; YAPP, F.; PATON, D. J. The detection of bovine viral diarrhoea virus in bulk milk samples by use of a single-tube RT-PCR. Veterinary Microbiology, v. 64, n. 2-3, p. 145-154, 1999.

ELVANDER, M. An experimental study of a concurrent primary infection with Bovine Respiratory Syncytical Virus (BRSV) and Bovine Viral Diarrhoea Virus (BVDV) in calves. 1996. Tese (Doutorado) - Swedish University of Agricultural Sciences, Uppsala, Sweden, 1996.

ENGELS, M.; METZLER, A.; WYLER, R. Ein Virus sucht seine Krankheit: Seroepizootologische Untersuchung über das Vorkommen der Bovinen Herpes Mammillitis in der Schweiz. Schweiz Archive Tierheilk, v. 121, p. 565$576,1979$.

ERSKINE, R. J.; BARTLETT, P. C.; SABO, K. M.; SORDILLO, L. M. Bovine leukemia virus infection in dairy cattle: effect on serological response to immunization against J5 escherichia coli bacterin. Veterinary Medicine International, v. 2011, article ID 915747, 2011. doi: 10.4061/2011/915747.

FRANCO-LUIZ, A. P. M.; FAGUNDES-PEREIRA, A.; COSTA, G. B.; ALVES, P. A.; OLIVEIRA, D. B.; BONJARDIM, C. A.; FERREIRA, P. C. P.; TRINDADE, G. S.; PANEI, C. J.; GALOSI, C. M.; ABRAHÃO, J. S.; KROON, E. G. Spread of Vaccinia virus to cattle herds, Argentina, 2011. Emerging Infectious Diseases, v. 20, n. 9, p. 1576-1578, 2014. doi: 10.3201/eid2009.140154.

FRANCO-LUIZ, A. P. M.; OLIVEIRA, D. B.; FAGUNDES-PEREIRA, A.; GASPARINI, M. C. S.; BONJARDIM, C. A.; FERREIRA, P. C. P.; TRINDADE, G. S.; PUENTES, R.; FURTADO, A.; ABRAHÃO, J. S.; LIMA, M. T. Detection of Vaccinia Virus in dairy cattle serum samples from 2009, Uruguay. Emerging Infectious Diseases, v. 22, n. 12, p. 2174-2177, 2016. doi: $10.3201 /$ eid2212.160447.

GIBBS, E. P. J.; JOHNSON, R. H.; OSBORNE, A. D. Experimental studies of the epidemiology of bovine herpes mammillitis. Research in Veterinary Science, v. 14, n. 2, p. 139-144, 1973.
GIBBS, E. P.; RWEYEMAMU, M. M. Bovine herpesviruses. Part II. Bovine herpesviruses 2 and 3. Veterinary Bulletin, v. 47, p. 411-425, 1977.

GILLET, N.; FLORINS, A.; BOXUS, M.; BURTEAU, C.; NIGRO, A.; VANDERMEERS, F.; BALON, H.; BOUZAR, A. B.; DEFOICHE, J.; BURNY, A.; REICHERT, M.; KETTMAN, R.; WILLEMS, L. Mechanisms of leukomogenesis induced by bovine leukemia virus: prospects for novel anti-retroviral therapies in human. Retrovirology, v. 4, n. 18, p. 1-32, 2007. doi: 10.1186/17424690-4-18.

GONÇALVES, D. A.; SPILKI, F. R.; CHIMINAZZO, C.; OLIVEIRA, M. A.; FRANCO, A. C.; ROEHE, P. M. Isolamento do vírus Parainfluenza bovino tipo 3 no Rio Grande do Sul, Brasil. Ciência Rural, v. 33, n. 5, p. 953 956, 2003. doi: 10.1590/S0103-84782003000500025.

GORAYA, M. U.; QURESHI, Z. A.; ABBAS, M.; ASHRAF, M.; MUNIR, M. Isolation of buffalo poxvirus from clinical case and variations in the genetics of the B5R gene over fifty passages. Virus Genes, v. 51, n. 1, p. 45-50, 2015. doi: 10.1007/s11262-015-1209-6.

GRAHAN, D. A. Bovine herpes virus-1 (BoHV-1) in cattle-a review with emphasis on reproductive impacts and the emergence of infection in Ireland and the United Kingdom. Irish Veterinary Journal, v. 66, n. 15, p. 1-11, 2013. doi: 10.1186/2046-0481-66-15.

GUTIÉRREZ, G.; LOMONACO, M.; ALVAREZ, I.; FERNANDEZ, F.; TRONO, K. Characterization of colostrum from dams of BLV endemic dairy herds. Veterinary Microbiology, v. 177, n. 3-4, p. 366-369, 2015. doi: 10.1016/j.vetmic.2015.03.001.

GUY, J. S.; POTGIETER, N. D.; MCCRACKEN, M.; MARTIN, W. Isolation of bovine herpesvirus-1 from vesicular lesions of bovine udder. American Journal of Veterinary Research, v. 45, p. 783-785, 1984.

HORZINEK, M. M. Pestivirus-taxonomic perspectives. Archives of Virology, v. 3, p.1-5, 1991. Supplement.

INTERNATIONAL COMMITTEE ON TAXONOMY OF VIRUSES (ICTV). 2018. Available from: <https://goo.gl/8gmKEe>. Viewed: 10 May 2018.

JAWORSKI, J. P.; PORTA, N. G.; GUTIERREZ, G.; POLITZKI, R. P.; ÁlVAREZ, I.; GALARZA, R.; ABDALA, A.; CALVINHO, L.; TRONO, K. G. Short 
communication: Relationship between the level of bovine leukemia virus antibody and provirus in blood and milk of cows from a naturally infected herd. Journal of Dairy Science, v. 99, n. 7, p. 5629-5634, 2016. doi: 10.3168/jds.2015-10813.

KAHRS, R. F. Herpes mammillitis and pseudo lumpy skin disease. Poxvirus infections of the teats. In: KAHRS, R. F. Viral diseases of cattle. 2 ed. Iowa: University Press, 2001. p. 151-157, 201-208.

KANNO, T.; ISHIHARA, R.; HATAMA, S.; OUE, J.; EDAMATSU, H.; KONNO, Y.; TACHIBANA, S.; MURAKAMI, K. Effect of freezing treatment on colostrum to prevent the transmission of Bovine Leukemia Virus. Journal of Veterinary Medical Science, v. 76, n. 2, p. 255-257, 2014. doi: 10.1292/jvms.13-0253.

KAWAKAMI, Y.; KAJI, T.; KUME, T.; OMURO, M.; HIRAMUNE, T.; MURASE, N.; MATUMOTO, M. Infection of cattle with parainfluenza 3 virus with special reference to udder infection. I. Virus isolation from milk. Japanese Journal of Microbiology, v. 10, n. 3, p. 159-169, 1966. doi: 10.1111/j.1348-0421.1966.tb00304.x.

KRÜGER, E. R. Herpesvírus bovino 4 (BoHV-4): isolamento e caracterização; desenvolvimento de Elisa indireto para diagnóstico. 2012. 87 f. Tese (Doutorado em Processos Biotecnológicos) - Universidade Federal do Paraná, Curitiba, 2012.

LEMOS, R. A. A; RIET-CORREA, F. Infecções víricas da pele do úbere em bovinos. In: RIET-CORREA, F.; SCHILD, A. L.; MENDEZ, M. D. C.; LEMOS, R. A. A. Doenças de ruminantes e equinos. São Paulo: Ed. Varela, 2001. p. 113-120.

LETCHWORTH, G. J.; CARMICHAEL, L. E. Local tissue temperature: a critical factor in the pathogenesis of bovid herpesvirus 2. Infection and Immunity, v. 43, n. 3, p. 1072-1079, 1984.

LEUZZI JUNIOR, L. A.; ALFIERI, A. F.; ALFIERI, A. A. Leucose enzoótica bovina e vírus da leucemia bovina. Semina: Ciências Agrárias, v. 22, n. 2, p. 211221, 2001. doi: 10.5433/1679-0359.2001v22n2p211.

LIMA, T. G. Produção e avaliação de anticorpos policlonais para vírus bovinos. 2013. $51 \mathrm{f}$. Dissertação (Mestrado em Ciência Animal) - Universidade Federal do Pampa, Uruguaiana, 2013.

LIN, T. M.; JIANG, M. J.; ENG, H. L.; SHI, G. Y.; LAI, L. C.; HUANG, B. J.; HUANG, K. Y.; WU, H. L. Experimental infection with bovine herpesvirus-4 enhances atherosclerotic process in rabbits. Laboratory
Investigation, v. 80 , n. 1, p. 3-11, 2000. doi: 10.1038/labinvest.3780002.

LOBATO, Z. I. P.; TRINDADE, G. S.; FROIS, M. C. M.; RIBEIRO, E. B. T.; DIAS, G. R. C.; TEIXEIRA, B. M.; LIMA, F. A.; ALMEIDA, G. M. F.; KROON, E. G. Outbreak of exantemal disease caused by Vaccinia virus in human and cattle in Zona da Mata region, Minas Gerais. Arquivo Brasileiro de Medicina Veterinária e Zootecnia, v. 57, n. 4, p. 423-429, 2005. doi: 10.1590/S0102-09352005000400001.

LYONS, N. A.; ALEXANDER, N.; STÄRK, K. D. C.; DULU, T. D.; RUSHTON, J.; FINE, P. E. Impact of foot-and-mouth disease on mastitis and culling on a large-scale dairy farm in Kenya. Veterinary Research, v. 46 , n. 41 , p. $1-11,2015$. doi: 10.1186/s13567-0150173-4.

MERCER, A. A.; SCHMIDT, A.; WEBER, O. (Ed.). Poxviruses. Basel: Birkhäuser Verlag, 2007.

MOERMAN, A.; STRAVER, P. J.; DE JONG, M. C. M.; QUAK, J.; BAANVINGER, T.; VAN OIRSCHOT, J. T. Clinical consequences of a bovine virus diarrhoea virus infection in a dairy herd: a longitudinal study. Veterinary Quarterly, v. 16, n. 2, p. 115-119, 1994. doi: 10.1080/01652176.1994.9694430.

MOHANTY, S. B.; HAMMOND, R. C.; LILLIE, M. G. A new bovine herpesvirus and its effect on experimentally infected calves. Archiv Fur Die Gesamte Virusforsch, v. 33, n. 3, p. 394-395, 1971.

MOSS, B. Poxviridae: the viruses and their replication. In: KNIPE, D. M.; HOWLEY, P. M. Field's Virology. 5 ed. Philadelphia: Wolters Kluwer Health/Lippincot Williams \& Wilkins, 2007. p. 905-2945.

MOTTON, D. D.; BUEHRING, G. C. Bovine leukemia virus alters growth properties and casein synthesis in mammary epithelial cells. Journal of Dairy Science, v. 86, n. 9, p. 2826-2838, 2003. doi: 10.3168/jds.S00220302(03)73880-6.

MURPHY, F. A.; GIBBS, E.; HORZINEK, M.; STUDDERT, M. Paramyxoviridae. In: MURPHY, F. A.; GIBBS, E.; HORZINEK, M.; STUDDERT, M. Veterinary virology. 3. ed. San Diego: Academic, 1999. p. 411-428.

MUYLKENS, B.; THIRY, J.; KIRTEN, P.; SCHYNTS, F.; THIRY, E. Bovine herpesvirus 1 infection and infectious bovine rhinotracheitis. Veterinary Research, v. 38, n. 2, p. 181-209, 2007. doi: 10.1051/vetres:2006059. 
NANDI, S.; KUMAR, M.; MANOHAR, M.; CHAUHAN, R. S. Bovine herpes virus infections in cattle. Animal Health Research Reviews, v. 10, n. 1, p. 85-98, 2009. doi: 10.1017/S1466252309990028.

NATIONAL MASTITIS COUNCIL (NMC). Recommended mastitis control program. 2016.

NISKANEN, R.; EMANUELSON, U.; SUNDBERG, J.; LARSSON, B.; ALENIUS, S. Effects of infection with bovine virus diarrhoea virus on health and reproductive performance in 213 dairy herds in one county in Sweden. Preventive Veterinary Medicine, v. 23, n. 3-4, p. 229-237, 1995. doi: 10.1016/0167-5877(94)00437-N.

NUOTIO, L.; NEUVONEN, E; HYYTIAINEM, M. Epidemiology and eradication of infectious bovine rhinotracheitis/infectious pustular vulvovaginitis (IBR/IPV) virus in Finland. Acta Veterinaria Scandinavica, v. 49, n. 3, 2007. doi: 10.1186/1751-0147-49-3.

PORCIONATO, M. A. F.; FERNANDES, A. M.; NETTO, A. S.; SANTOS, M. V. Influência do estresse calórico na produção e qualidade do leite. Revista Acadêmica: Ciência Agrária e Ambiental, v. 7, n. 4, p. 483-490, 2009.

POTGIETER, L. N. D.; MCCRACKEN, M. D.; HOPKINS, F. M.; WALKER, R. D.; GUY, J. S. Experimental production of bovine respiratory tract disease with viral diarrhea virus. American Journal of Veterinary Research, v. 45, n. 8, p. 1582-1585, 1984.

RADWAN, G. S.; BROCK, K. V.; HOGAN, J. S.; SMITH, K. L. Development of a PCR amplification assay as a screening test using bulk milk samples for identifying dairy herds infected with bovine viral diarrhea virus. Veterinary Microbiology, v. 44, n. 1, p. 77-92, 1995.

RAJÃO, D. S.; HEINEMANN, M. B.; REIS, J. K. P.; BRAZ, G. F.; HADDAD, J. P. A.; RIBEIRO, A. C. C. L.; LEITE, R. C. Effects of bovine leukemia virus infection on crossbred and purebred dairy cattle productive performance in Brazil. Semina: Ciências Agrárias, v. 35, n. 2, p. 891-900, 2014. doi: 10.5433/1679-0359.2014v35n2p891.

REED, D. E.; LANGPAPA, T. J.; ANSON, M. A. Characterization of herpesviruses isolated from lactating dairy cows with mammary pustular dermatitis. American Journal Veterinary Research, v. 38, n. 10, p. 1631-1634, 1977.

REHFELD, I. S.; GUEDES, M. I. M. C.; MATOS, A. C. D.; OLIVEIRA, T. M. L.; RIVETTI JUNIOR, A. V.; MOURA, A. C. J.; PAES, P. R. O.; LAGO, L. A.; KROON, E. G.; LOBATO, Z. I. P. Clinical, hematological, and biochemical parameters of dairy cows experimentally infected with Vaccinia virus. Research Veterinary Science, v. 95, n. 2, p. 752-757, 2013. doi: 10.1016/j.rvsc.2013.05.005.

REHFELD, I. S.; MATOS, A. C. D.; GUEDES, M. I. M. C.; COSTA, A. G. C.; FRAILHA, A. L. S.; LOBATO, Z. I. P. Subclinical bovine vaccinia: An important risk factor in the epidemiology of this zoonosis in cattle. Research in Veterinary Science, v. 114, p. 233-235, 2017. doi: 10.1016/j.rvsc.2017.03.022.

RODRIGUES, M.; XIMENES, F. H. B.; SILVA, J. R. B.; RODRIGUES, C. A. Análise do percentual de gordura do leite no diagnóstico precoce de enfermidades podais em vacas leiteiras. Revista Acadêmica: Ciência Animal, v. 15, p. S547-S548, 2017. Supplement 2. doi: 10.7213/cienciaanimal.v15iSuppl\%202.17907.

ROIZMAN, B.; DESROSIERS, R. C.; FLECKENSTEIN, B.; LOPEZ, C.; MINSON, A. C.; STUDDERT, M. J. The family Herpesviridae: an update. Archives of Virology, v. 123, n. 3-4, p. 425-449, 1992.

ROLA, J. G.; LARSKA, M.; GRZESZUK, M.; ROLA, J. Association between antibody status to bovine herpesvirus 1 and quality of milk in dairy herds in Poland. Journal of Dairy Science, v. 98, n. 2, p. 781789, 2015. doi: 10.3168/jds.2014-8781.

ROMERO, C. H.; CRUZ, G. B.; ROWE, C. A. Transmission of bovine leukemia virus in milk. Tropical Animal Health and Production, v. 15, n. 4, p. 215-218, 1983.

ROMERO, C. H.; ZANOCCHI, H. G.; AQUIAR, A. A.; ABARACON, D.; SILVA, A. G.; ROWE, C. A. Experimental transmission of enzootic bovine leucosis virus with blood and milk in the tropics. Pesquisa Veterinária Brasileira, v. 2, p. 9-15, 1982.

ROTH, J. A.; BOLIN, S. R.; FRANK, D. E. Lymphocyte blastogenesis and neutrophil function in cattle persistently infected with bovine viral diarrhea virus. American Journal of Veterinary Research, v. 47, n. 5, p. 1139-1141, 1986.

RWEYEMAMU, M. M.; JOHNSON, R. H.; LAURILLARD, R. E. Serological findings in bovine herpes mammillitis. British Veterinary Journal, v. 125, n. 7, p. 317-325, 1969. doi: 10.1016/S0007-1935(17)48858-0.

SANDEV, N.; KOLEVA, M.; BINEV, R.; ILIEVA, D. Influence of enzootic bovine leukosis virus upon the incidence of subclinical mastitis in cows at a different 
stage of infection. Veterinarski Arhiv, v. 74, n. 6, p. 411-416, 2004.

SCOTT, F. M.; MARTIN, W. B.; GOUDSWAARD, J. Antibodies to bovid herpesvirus 2 in the sera from cattle in the Netherlands. Veterinary Record, v. 102, n. 21, p. 464, 1978.

SIEGLER, H. H.; MARSCHANG, F.; MORSCHER, H. Beobachtungen über Zusammenhänge zwischen virusinfectionen und boviner mastitis. Tierarztliche Umschau, v. 39, p. 602-604, 1984.

SILVA, A. J.; SILVA, J. A.; BIANCHI, I. E.; MACEDO, B. G.; NEVES, C. G.; TEOBALDO, R. W. Correlation of the nutrients intake, production level and milk composition of grazing cows receiving concentrate supplementation. Revista Brasileira de Higiene e Sanidade Animal, v. 8, n. 5, p. 429-439, 2014. Supplement 1. doi: 10.5935/1981-2965.20140095.

SOUZA, F. N.; BLAGITZ, M. G.; LATORRE, A. O.; SANCHEZ, E. M. R.; BATISTA, C. F.; WEIGEL, R. A.; RENNÓ, F. P.; SUCUPIRA, M. C. A. DELLA LIBERA, A. M. M. P. Intracellular reactive oxygen production by polymorphonuclear leukocytes in bovine leukemia virus infected dairy cows. Journal of Veterinary Medical Science, v. 74, n. 2, p. 221-225, 2012. doi: 10.1292/jvms.110246.

SOUZA, F. N.; MONTEIRO, A. M.; SANTOS, P. R.; SANCHEZ, E. M. R.; BLAGITZ, M. G.; LATORRE, A. O.; FIGUEIREDO NETO, A. O.; GIDLUND, M.; DELLA LIBERA, A. M. M. P. Antioxidant status and biomarkers of oxidative stress in bovine leukemia-virus infected dairy cows. Veterinary Immunology and Immunopathology, v. 143, n. 1-2, p. 162-166, 2011. doi: 10.1016/j.vetimm.2011.05.028.

STRAUB, O. C.; KIELWEIN, G. Experimentelle mastitiden durch das Bläschenausschlagvirus des Rindes. Berliner Munchener Tierarztliche Wochenschrift, v. 79, p. $310-312,1966$.
TIZARD, I. R. Imunologia veterinária. 9. ed. São Paulo: Elsevier, 2014. 533 p.

TORRES, F. D.; BERNARDES, L. M.; WEIBLEN, R.; FLORES, E. F. Prevalence of antibodies to bovine herpes mammillitis virus in cattle of Rio Grande do Sul, Brazil. Ciência Rural, v. 39, n. 6, p. 1901-1904, 2009. doi: 10.1590/S0103-84782009005000116.

TRINDADE, G. S.; FONSECA, F. G.; MARQUES, J. T.; NOGUEIRA, M. L.; MENDES, L. C. N.; BORGES, A. S.; PEIRÓ, J. R.; PITUCO, E. M.; BONJARDIM, C. A.; FERREIRA, P. C. P.; KROON, E. G. Araçatuba vírus: a vaccinialike vírus associated with infection in humans and cattle. Emerging Infection Diseases, v. 9, n. 2, p. 155-160, 2003. doi: 10.3201/eid0902.020244.

WAAGE, S. Influence of new infection with bovine virus diarrhoea virus on udder health in Norwegian dairy cows. Preventive Veterinary Medicine, v. 20, n. 2, p. 123-135, 2000. doi: 10.1016/S0167-5877(99)00084-7.

WELLENBERG, G. J.; VAN DER POEL, W. H. M.; VAN DER VORST, T. J.; VAN VALKENGOED, P. H.; SCHUKKEN, Y. H.; WAGENAAR, F.; VAN OIRSCHOT, J. T. Bovine herpesvirus 4 in bovine clinical mastitis. Veterinary Record, v. 147, n. 8, p. 222- 225, 2000. doi: 10.1136/vr.147.8.222.

WELLENBERG, G. J.; VAN DER POEL, W. H. M.; VAN OIRSCHOT, J. T. Viral infections and bovine mastitis: a review. Veterinary Microbiology, v. 88, n. 1-2, p. 27-45, 2002. doi: 10.1016/S0378-1135(02)00098-6.

YOSHIKAWA, H.; XIE, B.; OYAMADA, T.; HIRAGA, A.; YOSHIKAWA, T. Detection of bovine leukemia viruses (BLV) in mammary tissues of BLV antibodypositive cows affected by subclinical mastitis. Journal of Veterinary Medical Science, v. 59, n. 4, p. 301-302, 1997.

ZADOKS, R. N.; ALLORE, H. G.; BARKEMA, H. W.; SAMPIMON, O. C.; WELLENBERG, G. J.; GRÖHN, Y. T.; SCHUKKEN, Y. H. Cow and quarter level risk factors for Streptococcus uberis and Staphylococcus aureus mastitis. Journal of Dairy Science, v. 84, n. 12, p. 26492663, 2001. doi: 10.3168/jds.S0022-0302(01)74719-4 